\title{
An association between TRP64ARG polymorphism of the B3 adrenoreceptor gene and some metabolic disturbances
}

\author{
Aibek E Mirrakhimov ${ }^{1,2^{*}}$, Alina S Kerimkulova², Olga S Lunegova' ${ }^{1}$ Cholpon B Moldokeeva ${ }^{3}$, Yulia V Zalesskaya',
} Samai S Abilova², Nurmira A Sovhozova ${ }^{4}$, Almaz A Aldashev ${ }^{4}$ and Erkin M Mirrakhimov²

\begin{abstract}
Backgrounds: B3 adrenoreceptors (ADRB3) are abundant in adipose tissue and play the role in its metabolism and lipolysis. Some variants of the ADRB3 gene may predispose subjects for the development obesity and metabolic abnormalities in the setting of modern sedentary lifestyle. ADRB3 gene polymorphism association with metabolic disturbances has never been studied before in the ethnic Kyrgyz population.

Aim: To study an association between Trp64Arg polymorphism of the ADRB3 and metabolic syndrome (MS) components in an ethnic Kyrgyz group.

Materials and methods: 213 Ethnic Kyrgyz volunteers over the age of 30 were enrolled in the study. The assessment plan for each individual comprised of general physical and anthropometric exams as well as laboratory tests (glucose, lipid panel, insulin) and genotyping by Trp64Arg polymorphism of the ADRB3. MS diagnosis was consistent with modified ATP III criteria (2005). Logistic regression analysis was performed to test the potential independent association between Arg64 allele with obesity, abdominal obesity (AO) and arterial hypertension (AH).

Results: Trp64Arg polymorphism of the ADRB3 was assessed in 213 individuals (145 men, 68 women) aged 30-73 (mean age $50.7 \pm 7.6$ ). Arg64 allele frequency was 0.239; ADRB3 genotype distribution among participants was: Trp64 homozygotes 54.5\%, Trp64Arg 43.2\% and Arg64 homozygotes 2.3\%. There was an association between Trp64Arg n Arg64Arg genotypes and higher BMI, WC and obesity frequency $(p<0.00009), A O(p<0.01)$, type 2 diabetes mellitus (DM) $(p<0.005)$ and lower high density cholesterol $(H D L-C)$ level $(p<0.03)$. The logistic regression analysis showed the correlation of the Arg64 allele with obesity (OR 3.159; 95\% Cl 1.789-5.577) and $\mathrm{AO}$ (OR 1.973; 95\% Cl 1.118-3.481). The association between Arg64 allele and AH lost its significance after adjustment for obesity.
\end{abstract}

Conclusion: Arg64 allele of the ADRB3 gene in the studied group has an association with MS components such as obesity, $\mathrm{AO}$ and decreased HDL-C level.

Keywords: metabolic syndrome, B adrenoreceptors, Trp64Arg polymorphism, abdominal obesity, dyslipidemia

\section{Introduction}

Changes in lifestyle of the world's population, which include increased intake of high-calorie food together with low physical activity, promote the rising prevalence of metabolic syndrome (MS), consisting of such risk factors as glucose metabolism abnormalities, dyslipidemia,

\footnotetext{
* Correspondence: amirrakhimov1@gmail.com

${ }^{1}$ National Centre of Cardiology and Internal medicine named by M.

Mirrakhimov, T.Moldo 3, Bishkek, 720040, Kyrgyzstan

Full list of author information is available at the end of the article
}

arterial hypertension $(\mathrm{AH})$ and obesity [1]. The presence of MS substantially increases the risk of the subsequent development of cardiovascular diseases [2] and type 2 diabetes mellitus [3] (DM).

Genetic predisposition plays a crucial role in the development of obesity besides traditionally acknowledged risk factors such as overeating and a sedentary lifestyle. Attempts to identify genes responsible for obesity were focused mostly on white and brown adipose tissues [4], which play an essential role in the regulation,

\section{C) Biomed Central}

(C) 2011 Mirrakhimov et al; licensee BioMed Central Ltd. This is an Open Access article distributed under the terms of the Creative Commons Attribution License (http://creativecommons.org/licenses/by/2.0), which permits unrestricted use, distribution, and reproduction in any medium, provided the original work is properly cited. 
storing and energy expenditure in mammals [5-7]. Stimulation of the ADRB3, which are abundant in visceral adipose tissue [8], activates adenylatecyclase, which in turn increases the amount of intracellular cAMP and thus causes enhanced lipolysis in white adipose tissue and free fatty acids delivery to the portal vein [9]. Thus, ADRB3 gene expression plays an important role in lipolysis [10].

Theoretically the functional alterations in ADRB3 may promote the development of obesity and insulin resistance (IR) $[11,12]$. Missense mutation in the ADRB3 causes the substitution of the coding sequences from tryptophan into arginine in $64^{\text {th }}$ position, and this point mutation is able to influence receptor's affinity to norepinephrine and its interaction with Gs proteins in adipocytes [13]. Some studies had shown the associations between Arg64 variant of the ADRB3 gene and early development of type $2 \mathrm{DM}$ and decreased early insulin response to glucose load [14], and, some studies with cellular transfection had shown an association with decreased glucose dependent insulin secretion [15].

Thereby ADRB3 gene is involved either directly or indirectly in lipid and glucose metabolism processes and may influence on endogenous energy balance and body mass regulation. At the same time, data about Trp64Arg polymorphism of the ADRB3 association with MS are inconsistent. Thus, approximately half of the studies found a positive association of the Trp64Arg polymorphism of the ADRB3 gene with obesity and IR [13,16-19], whereas the other studies didn't find any relationships between the presence of such polymorphism and obesity, type 2 DM or AH [20-22]. Such discordant results may be partially explained by ethnicity, age, or population differences in studied samples.

Previously Trp64Arg polymorphism of the ADRB3 gene had not been studied in the Kyrgyz population. The aim of this work was to study a possible association between this genetic polymorphism and MS components in an ethnic Kyrgyz group.

\section{Materials and methods Study population}

Inclusion criteria: ethnic Kyrgyz people over 30 years of age who were permanent residents at the time, non consanguine to each other, and willing to participate in the study.

Exclusion Criteria: surgical intervention within a month prior to study enrollment, severe kidney and/or liver disease, thyroid dysfunction, alcohol abuse, treatment with insulin, hypolipidemic and corticosteroid medications, pregnancy and lactation.

National Center of Cardiology and Internal Medicine and Kyrgyz State Medical Academy Ethics Committee approved the study protocol. All participants were informed about the aim and study protocol and gave written consent prior to enrollment.

Finally, 213 volunteers (145 men and 68 women) aged 30-73 (mean age $50.7 \pm 7.6$ ) years were included in the study.

All subjects completed the medical examination. Blood pressure (BP) was measured using standard sphygmomanometer in the sitting position after a 10 minute rest. Anthropometric data included body mass index (BMI) as a weight $(\mathrm{kg})$ to height $\left(\mathrm{m}^{2}\right)$ ratio, waist circumference (WC) and hip circumference (HC) measurements. Modified Adult Treatment Panel III criteria were used for the MS diagnosis. [1].

\section{Laboratory tests}

Blood collection from the cubital vein took place after 12 hours of fasting in the morning. Laboratory tests included fasting plasma glucose (FPG), lipid panel (total cholesterol (TC), triglycerides (TG), high density lipoprotein cholesterol (HDL-C)) and immunoreactive insulin levels. Low density lipoprotein cholesterol (LDL-C) was calculated by Friedwald W. formula [23]. IR index HOMA was calculated as $\operatorname{serum} \operatorname{insulin}(\mu \mathrm{IU} / \mathrm{ml}) \mathrm{x}$ plasma glucose $(\mathrm{mmol} / \mathrm{l}) / 22.5$. HOMA index $\geq 2.77$ was considered as IR presence. Lipid panel analysis was performed on «Sinhron CX4-DELTA» biochemical autoanalysator («Beckman», USA).

\section{Genotyping}

Genetic tests included DNA extraction with subsequent determination of Trp64Arg polymorphism of the ADRB3 gene. DNA was extracted from blood cells using «Nucleon BACC3» kit ("Amersham Pharmacia Biotech", Sweden). Trp64Arg of the ADRB3 polymorphism was detected using Restriction Fragment Length Polymorphism (RFLP) method. Polymerase chain reaction (PCR) was carried out on "Hybaid" amplificator (HBPX 220, Great Britain) with specific primers (F - CGCCCAATACCGCCAACAC and R - 3 CCACCAGGAGTCCCATCACC) and subsequent restriction of received PCR products by «BstOI» enzyme («Promega», USA). The received restriction fragments - Arg 64Arg 161 n.p., Trp64Arg 161+99+62 n.p., Trp64Trp np. were divided by electrophoresis in 3\% Agar gel. Gel scanning and analysis of received results were made on image-densitometer «Fluor-S Multimager» ("Bio-Rad", USA).

\section{Statistical analysis}

The "SPSS v. 17.0" and "Graph Pad PRIZM 5" software were used for statistical analyses. Student $t$ test and Mann-Whitney U - test were used to assess differences between continuous variables with normal and nonparametric distribution respectively. The $x^{2}$ test was carried out to study an association between categorical 
variables. The data are presented as mean \pm standard deviation (sd) for variables with normal distribution and median (25th and 75th percentile) for variables with nonparametric distribution. The logistic regression analysis was performed to test the potential independent association between Arg64 allele and obesity, AO, type $2 \mathrm{DM}$ and $\mathrm{AH}$. The $\mathrm{p}$ value $<0.05$ was considered as a cut off for statistical significance.

\section{Results}

ADRB3 genotypes were found to be in Hardy-Weinberg equilibrium. The frequency of Arg64 allele was 0.239 ( 0.269 and 0.176 in men and women respectively), ADRB3 genotype distribution forTrp64 homozygotes, Trp64Arg heterozygotes and Arg64 homozygotes were 54.5\% $(\mathrm{n}=116), 43.2 \%(\mathrm{n}=92)$ and $2.3 \%(\mathrm{n}=5)$ respectively. The Arg64Arg was rarely present in this sample, so all carriers of Arg64 allele were united in one group.

General characteristics of the included participants are present in Table 1.

Both groups were matched for age and smoking status, but it is noteworthy that there were more males in the Group \#2. Obesity $(\mathrm{p}<0.00009)$ and AO $(\mathrm{p}<0.01)$ were more prevalent in Trp64Arg and Arg64Arg genotypes, rather than in Trp64Trp genotype. Thus, BMI, WC and waist to hip ratio (WC/HC) were higher in the Group 2 (Table 1). Comparative associations of the ADRB3 genotypes with obesity parameters are present in the Figure 1.

Table 1 General characteristics of studied patients and correlation with risk factors:

\begin{tabular}{|c|c|c|c|}
\hline Parameters & $\begin{array}{l}\text { Group \#1 } \\
\text { Trp64Trp } \\
(n=116)\end{array}$ & $\begin{array}{l}\text { Group \# } 2 \\
\text { Trp64Arg + Arg64Arg } \\
(\mathrm{n}=97)\end{array}$ & $P$ \\
\hline Sex (Male) & $59 \%$ & $78 \%$ & 0.004 \\
\hline Age, years & $51.0 \pm 7.9$ & $50.4 \pm 7.3$ & $\mathrm{~ns}$ \\
\hline Obesity, \% & 29 & 55.2 & 0.00009 \\
\hline BMI, $\mathrm{kg} / \mathrm{m}^{2}$ & $27.7 \pm 4.5$ & $29.4 \pm 4.9$ & 0.008 \\
\hline $\mathrm{AO}, \%$ & 54.3 & 70.1 & 0.01 \\
\hline WC, cm & $94.9 \pm 13.2$ & $101.7 \pm 14$ & 0.0004 \\
\hline WC/HC & $0.95 \pm 0.13$ & $1.0 \pm 0.14$ & 0.028 \\
\hline $\mathrm{AH}, \%$ & 32.7 & 48.5 & 0.019 \\
\hline $\mathrm{SBP}, \mathrm{mmHg}$ & $134.3 \pm 23.4$ & $136.1 \pm 24.1$ & $\mathrm{~ns}$ \\
\hline $\mathrm{DBP}, \mathrm{mmHg}$ & $84.8 \pm 13.6$ & $87.1 \pm 13.2$ & $\mathrm{~ns}$ \\
\hline Type 2 DM, \% & $10.3 \%$ & $24.7 \%$ & 0.005 \\
\hline Fasting glycemia & $5.9 \pm 1.9$ & $6.05 \pm 2.02$ & ns \\
\hline Smoking, \% & 24.7 & 25 & ns \\
\hline $\mathrm{IR}, \%$ & $21.3 \%(n=80)$ & $28.3 \%(n=46)$ & $\mathrm{ns}$ \\
\hline MS, \% & $37.9 \%$ & $49.5 \%$ & ns \\
\hline
\end{tabular}

ns -non significant;
$\mathrm{AH}$ and type $2 \mathrm{DM}$ also were more frequent in the second group, but the differences in systolic and diastolic BP and fasting glucose plasma level between the two groups were not statistically significant. Individuals from Group \#2 comparing to the Trp64Trp genotype carriers had a trend towards higher insulin levels and higher frequency of IR and MS, but aforementioned parameters did not reach statistical significance (table 2).

Lipid profile components except the HDL-C level were approximately identical among both groups. HDL$C$ level was lower in Arg64 allele carriers ( $p<0.03)$. Comparative associations of the ADRB3 genotypes with HDL-C level are present in the Figure 2.

The results of $x^{2}$ tests demonstrated the positive association between carrying the Arg64 allele and main MS components such as obesity $\left(\mathrm{x}^{2}=17.49 ; \mathrm{p}<0.0001\right)$, abdominal obesity $(\mathrm{AO})\left(\mathrm{x}^{2}=5.56 ; \mathrm{p}<0.018\right), \mathrm{AH}\left(\mathrm{x}^{2}=\right.$ $5.5 ; \mathrm{p}<0.019)$ and type $2 \mathrm{DM}\left(\mathrm{x}^{2}=7.8 ; \mathrm{p}<0.0053\right)$ (table 3).

In a forward stepwise logistic regression model that included obesity as a dependent variable and the polymorphism of the ADRB3 (with Trp64 allele as reference) and sex as independent variables, only the presence of the Arg64 allele reached statistical significance (OR 3.16; 95\% CI 1.79-5.56). In the same regression model with $\mathrm{AO}$ as the dependent variable the similar results were obtained (OR 1.97; 95\% CI 1.123.48). For $\mathrm{AH}$ and type $2 \mathrm{DM}$ after including only sex and polymorphism of the ADRB3 as independent variables the Arg64 allele increased the odds ratio for $\mathrm{AH}$ (OR 1.92; 95\% CI 1.1-3.6) and for type 2 DM (OR 2.85; 95\% CI 1.34-6.06), but after adjusting for obesity the role of Arg64 allele lost its statistical significance in both models.

\section{Discussion}

In this study, we found that among ethnic Kyrgyz people the Trp64Trp genotype was more frequent and was discovered in 116 studied persons (54.5\%). The Arg64Arg genotype was present only in 5 participants. The presence of Arg64 allele in our study showed a strong association with obesity and $\mathrm{AO}$ as well as greater WC and BMI, even after adjustment for gender.

It is well known that obesity is one of the most important risk factors for type 2 DM development, reflecting not only severity and duration of obesity, but also fat distribution [3]. From a theoretical point of view, it seems plausible that altered function of ADRB3 may promote the development of obesity through enhanced lipid accumulation in white adipose tissue and decreased biological energy expenditure from brown adipose tissue as a result of decreased lipolysis [18,19]. It was shown that ADRB3 mRNA is abundantly present in visceral adipose tissue, compared with subcutaneous fat [9]. 


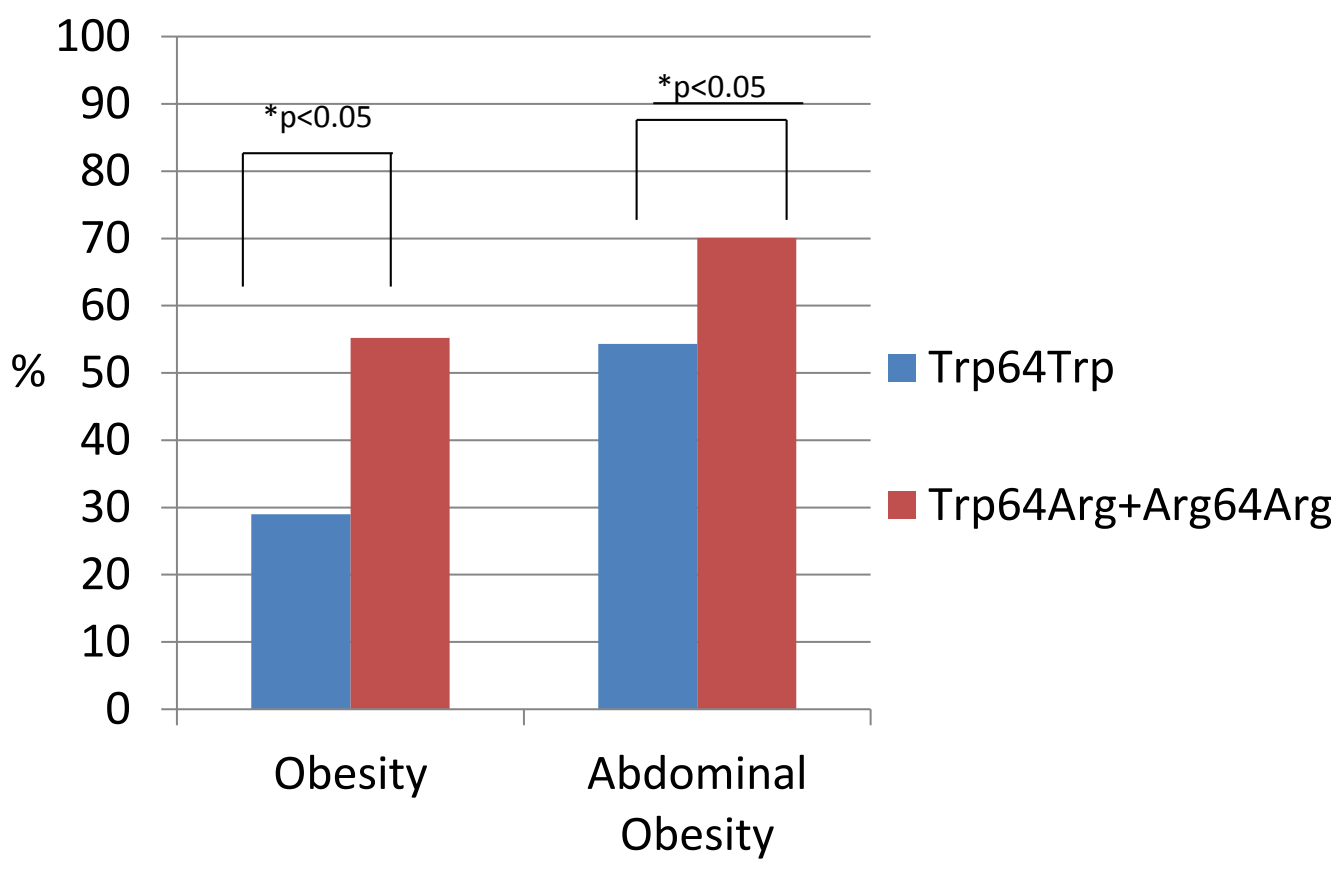

Figure 1 ADRB3 genotypes and obesity parameters.

Diminished lipid oxidation may serve as a predictor of subsequent increase of fat amount in the human organism [24]. Some studies had shown associations between obesity and Trp64Arg polymorphism of the ADRB3 gene [25], but not others [26,27]. In studies focused on ADRB3 gene polymorphism and BMI, there was a stronger association between in Asian population, compared to Caucasians $[28,29]$. The Chinese researchers had shown that ADRB3 R64 allele was associated with increased BMI and weight [30] and research group from Poland had found the protective effects of the ADRB3 Arg64 polymorphism against metabolic disorders [31].

Results of the studies focused on Trp64Arg carrier state association with MS are also controversial. Some found a correlation between this polymorphism and body weight and BMI variables [32], whereas others detected that W64 allele homozygotes of the ADRB3 are

Table 2 Laboratory test results and relationship with MS and IR.

\begin{tabular}{llll}
\hline Parameters & $\begin{array}{l}\text { Group \#1 } \\
\text { Trp64Trp } \\
(\mathbf{n}=\mathbf{1 1 6})\end{array}$ & $\begin{array}{l}\text { Group \#2 } \\
\text { Trp64Arg + Arg64Arg } \\
(\mathbf{n}=\mathbf{9 7})\end{array}$ & $\mathbf{P}$ \\
\hline $\mathrm{TC}, \mathrm{mmol} / \mathrm{l}$ & $5.14 \pm 1.08$ & $4.92 \pm 0.9$ & $\mathrm{~ns}$ \\
\hline $\mathrm{LDL}-\mathrm{C}, \mathrm{mmol} / \mathrm{l}$ & $3.23 \pm 0.92$ & $3.12 \pm 0.8$ & $\mathrm{~ns}$ \\
\hline $\mathrm{HDL}-\mathrm{C}, \mathrm{mmol} / \mathrm{l}$ & $1.12 \pm 0.34$ & $1.02 \pm 0.33$ & 0.03 \\
\hline $\mathrm{TG}, \mathrm{mmol} / \mathrm{l}$ & $1.36(0.92 ; 2.1)$ & $1.42(1.08 ; 2.22)$ & $\mathrm{ns}$ \\
\hline Insulin, $\mu \mathrm{l} / \mathrm{m} / \mathrm{ml}$ & $6.65(4.8 ; 9.89)(\mathrm{n}=80)$ & $\begin{array}{l}8.28(4.24 ; 11.8) \\
(\mathrm{n}=46)\end{array}$ & $\mathrm{ns}$ \\
\hline
\end{tabular}

ns -non significant relatively protected against metabolic abnormalities [30]. In the Quebec Family Study researchers did not find any differences in glucose, insulin levels and BP values in studied groups with and without Arg64 allele [22]. Japanese researchers found ADRB3 polymorphism association with IR, but not with dyslipidemia [33]. Also prior investigations did not find statistically significant relationships between ADRB3 genotype and type 2 DM $[13,17,34]$. Nevertheless it reached statistical significance in the meta analysis performed by Fujisawa $\mathrm{T}$ et al. [33]. In our study the frequency of type $2 \mathrm{DM}$ in Trp64Arg and Arg64Arg group was higher but the association lost its significance after adjustment for obesity.

Experimental data clearly shows that, besides its effect on lipolysis and biological energy production, ADRB3 may modulate peripheral vascular tone and increase the BP [35]. Some clinical studies pointed on possible relationship between $\mathrm{AH}$ and Trp64Arg polymorphism $[17,35,36]$, as well as relationship between this genotype and higher mortality among hypertensives [37]. In our study, we found an association of Trp64Arg carrier state with $\mathrm{AH}(\mathrm{p}<0.019)$. After logistic regression analysis, including gender and ADRB3, the association was still statistically significant, but after including obesity in the list, ADRB3 lost its significance. It seems that AH as well as most other disorders are polygenic in nature where many genes and environmental factors play a role in the pathogenesis. It may be speculated that Arg64 allele may indirectly affect $\mathrm{AH}$ risk through the development of obesity. In a recently published Japanese work 


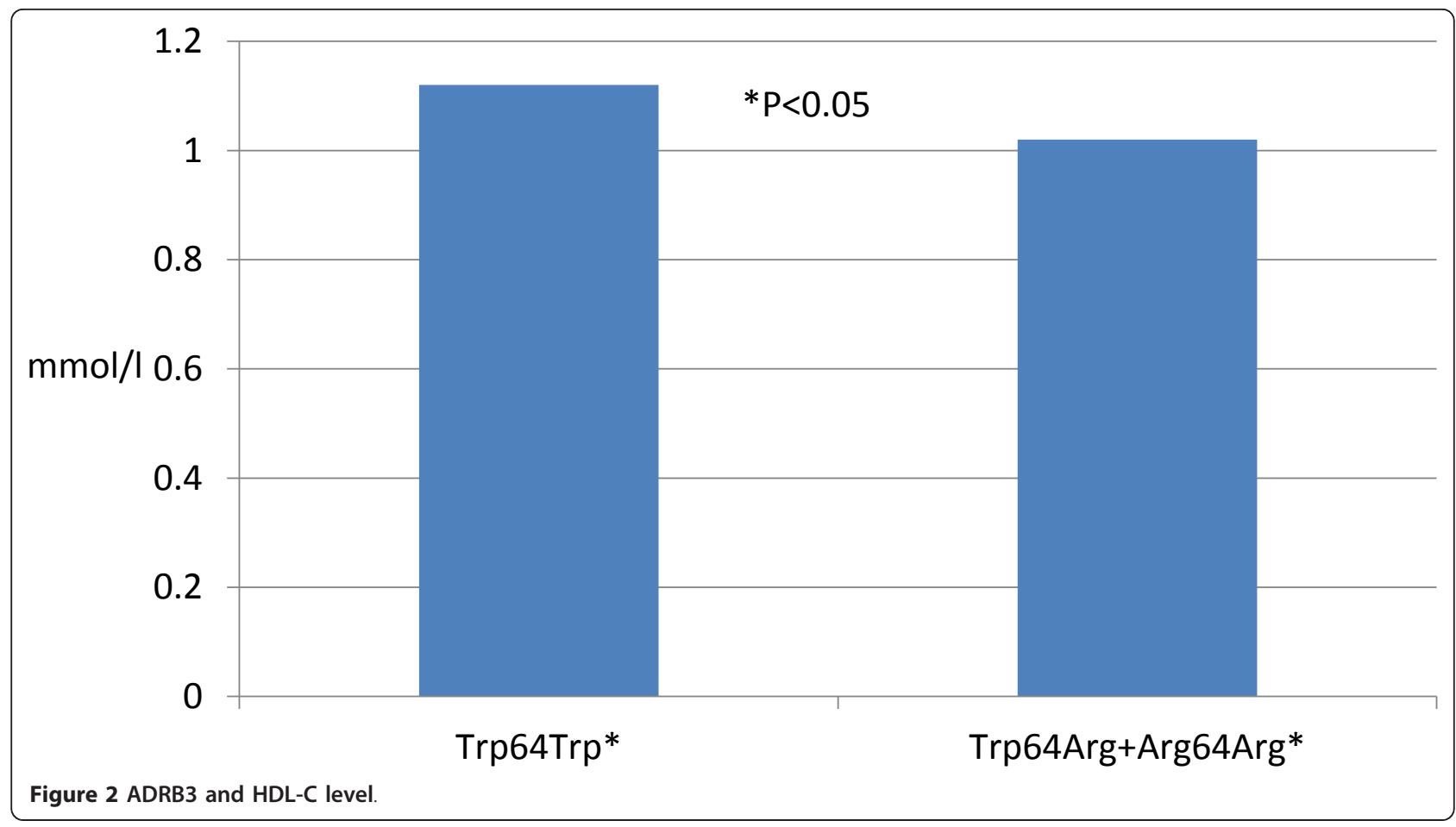

it was clearly shown that Trp64Arg polymorphism is associated with cardiovascular risk among hypertensive [31]. Besides the ADRB3, some genetic variants of the cardiac B 1 adrenoreceptor may play a role in the development of left ventricular hypertrophy in patients after acute coronary event in patients without $\mathrm{DM}$ or $\mathrm{AH}$ [38]. This highlights the possibility of altered sympathetic signaling in the pathogenesis of cardiovascular disease.

Data on the ADRB3 gene mutation effect on lipid metabolism are inconsistent and heterogeneous. Some studies did not find any correlation between Arg64 allele and serum lipids $[17,22]$. On the other hand, a study conducted on a young Danish population showed, that this mutation had an associations with hypertriglyceridemia and increased LDL-C levels [39]. Recently published data in Spain about Trp64Arg carrier state in hypertensive cohort had shown associations with higher BMI and TC level [40]. In our sample, Trp64Arg carriers had lower HDL-C levels, but other cholesterol metabolism parameters did not reach statistical significance.

Table 3 Trp64Trp, Trp64Arg and Arg64Arg genotypes of the B3AR gene and their correlation with AO, AH and DM type 2.

\begin{tabular}{llll}
\hline & Trp64Trp, $\mathbf{n}(\%), \mathbf{n}=\mathbf{1 1 6}$ & $\begin{array}{l}\text { Trp64Arg andArg64Arg, } \\
\mathbf{n}(\mathbf{\%}) \mathbf{n}=\mathbf{9 7}\end{array}$ & $\mathbf{x}^{\mathbf{2}} ; \mathbf{p}$ \\
\hline $\begin{array}{lll}\text { Obesity: } \\
\text { yes }\end{array}$ & $56(57.7)$ & $x^{2}=17.49 ; p<0.0001$ \\
no & $82(70.7)$ & $41(42.3)$ & $x^{2}=5.56 ; p=0.018$ \\
\hline AO: & $63(54.3)$ & $68(70.1)$ & \\
yes & $53(45.7)$ & $29(29.9)$ & $x^{2}=5.5 ; p=0.019$ \\
no & $39(33.6)$ & $48(49.5)$ & \\
\hline AH: & $77(66.4)$ & $49(50.5)$ & $x^{2}=7.8 ; p=0.0053$ \\
yes & $12(10.3)$ & $24(24.7)$ & \\
\hline no & $104(89.7)$ & $73(75.3)$ & \\
\hline DM 2: & & & \\
yes & & & \\
\hline
\end{tabular}




\section{Conclusion}

Our work was the first in studying Trp64Arg polymorphism among ethnic Kyrgyz people, where we found an association of this ADRB3 gene polymorphism with components of MS, such as obesity, AO, and decreased HDL-C level. This study and its findings may be useful and provide some basic information regarding our understanding of complex pathological interconnections between metabolic heritage and modern environment.

\section{Abbreviations}

ADRB3: B3 adrenoreceptor; AH: arterial hypertension; AO: abdominal obesity; BMI: body mass index; DBP: diastolic blood pressure; DM: diabetes mellitus; HC: hip circumference; HDL: C-high density cholesterol; IR: insulin resistance; LDL-C: low density cholesterol; MS:metabolic syndrome; SBP: systolic blood pressure; TC: total cholesterol; TG:triglycerides; WC: waist circumference

\section{Author details}

'National Centre of Cardiology and Internal medicine named by $\mathrm{M}$. Mirrakhimov, T.Moldo 3, Bishkek, 720040, Kyrgyzstan. ${ }^{2}$ Kyrgyz State Medical Academy named by I.K. Akhunbaev, Akhunbaev street 92, Bishkek, 720020, Kyrgyzstan. ${ }^{3}$ Kyrgyz-Russian Slavic University named by B.N. Eltsyn; Kievskaya 44, Bishkek, 720000, Kyrgyzstan. Institute of Molecular Biology and Medicine, T.Moldo 3, Bishkek, 720040, Kyrgyzstan.

\section{Authors' contributions}

All authors contributed equally during the investigation process and article writing. All authors participated in manuscript discussion. All authors have read and approved the final manuscript. AEM performed English translation and revision of the manuscript.

\section{Competing interests}

The authors declare that they have no competing interests.

Received: 15 August 2011 Accepted: 12 October 2011

Published: 12 October 2011

\section{References}

1. Grundy SM, Cleeman JI, Daniels SR, Donato KA, Eckel RH, Franklin BA, et al: Diagnosis and management of the metabolic syndrome: an American Heart Association/National Heart, Lung and Blood Institute scientific statement. Curr Opin Cardiol 2006, 21:1-6.

2. Sattar N, Gaw A, Scherbakova O, Ford I, O'Reilly DS, Haffner SM, et al: Metabolic syndrome with and without C-reactive protein as a predictor of coronary heart disease and diabetes in the West of Scotland Coronary Prevention Study. Circulation 2003, 108:414-419.

3. Lorenzo C, Okoloise M, Williams K, Stern MP, Haffner SM: The metabolic syndrome as predictor of type 2 diabetes: the San Antonio heart study. Diabetes Care 2003, 26:3153-3159.

4. Arner P: Hunting for human obesity genes? Look in the adipose tissue. Int J Obes Relat Metab Disord 2000, 24:S57-S62.

5. Zaagsma J, Nahorski SR: Is the adipocyte b-adrenoceptor a prototype for the recently cloned atypical b3-adrenoceptor? Trends Pharmacol Sci 1990, 11:3-7.

6. Lofontan M, Berlan M: Fat cell adrenergic receptors and the control of white and brown fat cell function. J Lipid Res 1993, 34:1057-1091.

7. Katzmarzyk P, Perusse L, Bouchard C: Genetics of abdominal visceral fat levels. Am J Hum Biol 1999, 11:225-235.

8. Krief $S$, Strosberg AD, Nyberg $S$, Emorine $L$, Arner P: Tissue distribution of B3-adrenergic receptor mRNA in man. J Clin Invest 1993, 91:344-349.

9. Lönnqvist F, Thöme A, Nilsell K, Hoffstedt J, Arner P: A pathogenic role of visceral fat b3-adrenoceptors in obesity. J Clin Invest 1995, 95:1109-1116.

10. Arch JRS, Kaumann AJ: B3 and atypical b-adrenoceptors. Med Res Rev 1993, 13:663-729.

11. Clement K, Manning BS, Basdevant A, Strosberg AD, Guy-Grand B, Froguel P: Gender effect of theTrp64Arg mutation in the b3-adrenergic receptor gene on weight gain in morbid obesity. Diabetes Metab 1997, 23:424-427.

12. Li LS, Lönnqvist F, Luthman H, Arner P: Phenotypic characterization of the Trp64Arg polymorphism in the $b_{3}$-adrenergic receptor gene in normal weight and obese subjects. Diabetologia 1996, 39:857-860.

13. Walston J, Silver K, Bogardus C, Knowler WC, Celi FS, Austin S, et al: Time of onset of non-insulin-dependent diabetes mellitus and genetic variation in the b3-adrenergic-receptor-gene. N Engl J Med 1995, 333:343-347.

14. Walston J, Silver K, Hilfiker H, Andersen RE, Seibert M, BeamerBet al: Insulin response to glucose is lower in individuals homozygous for the Arg64 variant of the beta-3-adrenergic receptor. J Clin Endocrinol Metab 2000, 85:4019-4022.

15. Perfetti R, Hui H, Chamie K, Binder $S$, Seibert M, McLenithan J, et al: Pancreatic beta-cells expressing the Arg64 variant of the beta(3)adrenergic receptor exhibit abnormal insulin secretory activity. $\mathrm{J} \mathrm{Mol}$ Endocrinol 2001, 27:133-144.

16. Kadowaki H, Yasuda K, Iwamoto K, Otabe S, Shimokawa K, Silver K, et al: A mutation in the b3-adrenergic receptor gene is associated with obesity and hyperinsulinemia in Japanese subjects. Biochem Biophys Res Commun 1995, 215:555-560.

17. Widen E, Lehto M, Kanninen T, Walston J, Shuldiner AR, Groop LC Association of a polymorphism in the B3-adrenergic receptor gene with features of the insulin resistance syndrome in Finns. N Engl J Med 1995, 333:348-351.

18. Kurabayashi T, Carey DGP, Morrison NA: The B3 adrenergic receptor gene Trp64Arg mutation is over presented in obese women: effects on weight, BMI, abdominal fat, blood pressure, and reproductive history in an elderly Australian population. Diabetes 1996, 45:1358-1363.

19. Proenza AM, Poissonnet CM, Ozata M, Ozen S, Guran S, Palou A, et al: Association of sets of alleles of genes encoding b3-adrenoreceptor, uncoupling protein 1 and lipoprotein lipase with increased risk of metabolic complications in obesity. Int J Obes Relat Metab Disord 2000 24:93-100.

20. Oeveren van-Dybicz AM, Vonkeman HE, Bon MA, van den Bergh FA Vermes I: B3-adrenergic receptor gene polymorphism and type 2 diabetes in a Caucasian population. Diabetes Obes Metab 2001, 3:47-51.

21. Awata T, Katayama S: Genetic variation in the b3-adrenergic receptor in Japanese NIDDM patients. Diabetes Care 1996, 19:271-272.

22. Gagnon J, Mauriege P, Roy S, Sjostrom D, Chagnon YC, Dionne FT, et al: The Trp64Argmutation of the b3-adrenergic receptor gene has no effect on obesity phenotypes in the Quebec family study and Swedish obese subjects cohorts. J Clin Invest 1996, 98:2086-2093.

23. Friedewald WT, Levy Rl, Fredrickson DS: Estimation of the concentration of low density lipoprotein cholesterol in plasma, without use of the preparative ultracentrifuge. Clin Chem 1972, 18:499-502.

24. Astrup A, Buemann B, Toubro S: Fat metabolism in the prediction to obesity. Ann NY Acad Sci 1997, 827:417-428.

25. Strazzullo P, lacone R, Siani A, Cappuccio FP, Russo O, Barba G, et al Relationship of Trp64Arg polymorphism of the beta3 adrenoceptor gene to central adiposity and high blood pressure: interaction with age. Cross-sectional and longitudinal findings of the Olivetti prospective heart study. J Hypertens 2001, 19:399-406.

26. Büettner R, Schäffler A, Arndt H, Rogler G, Nusser J, Zietz B, et al: The Trp64Arg polymorphism of the b3-adrenergic receptor gene is not associated with obesity or type 2 diabetes mellitus in a large population-based Caucasian cohort. J Clin Endocrinol Metab 1998, 83:2892-2897.

27. Ghosh S, Langefeld CD, Ally D, Watanabe RM, Hauser ER, Magnuson VL, et al: The W64R variant of the b3-adrenergic receptor is not associated with type II diabetes or obesity in a large Finnish sample. Diabetologia 1999, 42:238-244.

28. Fujisawa T, Ikegami H, Kawaguchi Y, Ogihara T: Meta-analysis of the association of Trp64Arg polymorphism of beta 3-adrenergic receptor gene with body mass index. J Clin Endocrinol Metab 1998, 83:2441-2444.

29. Kurokawa N, Nakai K, Kameo S, Liu ZM, Satoh H: Association of BMI with the b3-adrenergic receptor gene polymorphism in Japanese: metaanalysis. Obes Res 2001, 9:741-5.

30. Walston J, Silver K, Shuldiner AR: The B3-adrenergic receptor and susceptibility to obesity, the insulin resistance syndrome, and noninsulin-dependent diabetes mellitus.Edited by: Spiegel AM. Contemporary 
Endocrinology: G Proteins, Receptors, and Disease. Totowa, NJ: Humana Press Inc:; 1997:301-318.

31. Malczewska-Malec M, Wybrańska I, Leszczyńska-Gołabek I, Niedbał S, Kwaśniak M, Hartwich J, et al: An analysis of the link between polymorphisms of the beta2 and beta3 adrenergic receptor gene and metabolic parameters among Polish Caucasians with familial obesity. Med Sci Monit 2003, 9(6):CR 225-234.

32. Urhammer SA, Clausen JO, Hansen T, Pedersen O: Insulin sensitivity and body weight changes in young white carriers of the codon64 amino acid polymorphism of the B3-adrenergic receptor gene. Diabetes 1996, 45:1115-1120.

33. Büettner R, Schäffler A, Arndt H, Rogler G, Nusser J, Zietz B, et al: The Trp64Arg polymorphism of the b3-adrenergic receptor gene is not associated with obesity or type 2 diabetes mellitus in a large population-based Caucasian cohort. J Clin Endocrinol Metab 1998, 83:2892-2897.

34. Fujisawa T, Ikegami H, Yamato E, Takekawa K, Nakagawa Y, Hamada Y, et al: Association of Trp64Arg mutation of the b3-adrenergic-receptor with type 2 diabetes and body weight gain. Diabetologia 1996, 39:349-52.

35. Shen YT, Zhang H, Vatner SF: Peripheral vascular effects of B3-adrenergic receptor stimulation in conscious dogs. J Pharmacol Exp Ther 1994, 268:466-473.

36. Tonolo G, Melis MG, Secchi G, Atzeni MM, Angius MF, Carboni A, et al: Association of Trp64Arg B3-Adrenergic-receptor gene polymorphism with essential hypertension in the Sardinian population. J Hypertens 1999, 17:33-38.

37. Iwamoto $Y$, Ohishi M, Yuan M, Tatara Y, Kato N, Takeya Y, et al: BAdrenergic receptor gene polymorphism is a genetic risk factor for cardiovascular disease: a cohort study with hypertensive patients. Hypertens Res 2011, 34(5):573-577.

38. Hakalahti AE, Tapanainen JM, Junttila JM, Kaikkonen KS, Huikuri HV, PetäjäRepo UE: Association of the Beta-1 adrenergic receptor carboxyl terminal variants with left ventricular hypertrophy among diabetic and nondiabetic survivors of acute myocardial infarction. Cardiovasc Diabetol 2010, 9:42.

39. Urhammer SA, Clausen JO, Hansen T, Pedersen O: Insulin sensitivity and body weight changes in young white carriers of the codon64 amino acid polymorphism of the B3-adrenergic receptor gene. Diabetes 1996, 45:1115-1120.

40. Corella D, Guillern M, Portoler's O, Sorli JV, Alonso V, Folch J, et al: Gender specific associations of the Trp64Arg mutation in the B3-adrenergic receptor gene with obesity-related phenotypes in a Mediterranean population: interaction with a common lipoprotein lipase gene variation. J Intern Med 2001, 25:348-360.

doi:10.1186/1475-2840-10-89

Cite this article as: Mirrakhimov et al:: An association between

TRP64ARG polymorphism of the B3 adrenoreceptor gene and some metabolic disturbances. Cardiovascular Diabetology 2011 10:89.

\section{Submit your next manuscript to BioMed Central and take full advantage of:}

- Convenient online submission

- Thorough peer review

- No space constraints or color figure charges

- Immediate publication on acceptance

- Inclusion in PubMed, CAS, Scopus and Google Scholar

- Research which is freely available for redistribution

Submit your manuscript at www.biomedcentral.com/submit
Biomed Central 